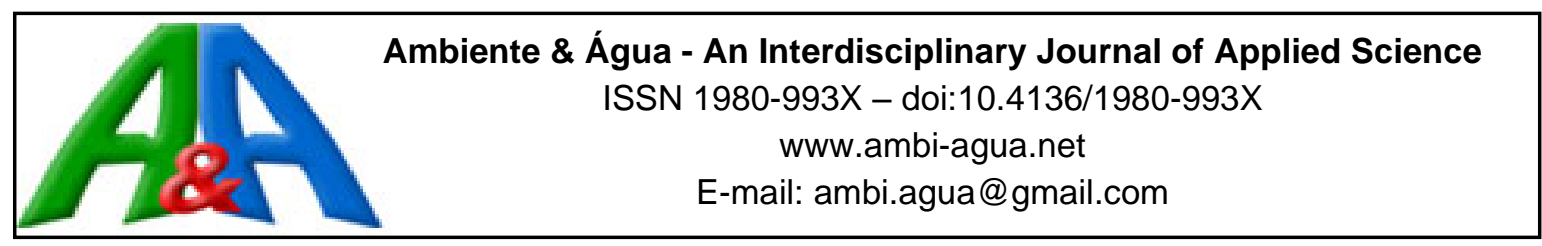

\title{
Removal of nutrients from aquaculture residual water: A review
}

\author{
ARTICLES doi:10.4136/ambi-agua.2747
}

Received: 07 May 2021; Accepted: 26 Oct. 2021

\author{
Jéssica Mendonça Ribeiro Cargnin (iD; Jair Juarez João*(i) \\ Centro Tecnológico. Universidade do Sul de Santa Catarina (UNISUL), Avenida José Acácio Moreira, $n^{\circ} 787$, \\ CEP: 88704-900, Tubarão, SC, Brazil. E-mail: jessica.mribeiiro@gmail.com \\ *Corresponding author. E-mail: jair.joao@unisul.br
}

\begin{abstract}
Aquaculture plays an important role in providing protein-rich foods, meeting the growing demand for fish. However, aquaculture is a potentially polluting activity, especially with regard to water pollution, due to the improper disposal of wastewater from the production process. Aquaculture wastewater is rich in nutrients (ammonia, nitrate, nitrite and phosphorus) and organic matter, and is commonly discharged into the environment without proper treatment. This can cause a series of environmental impacts and aggravate the current water crisis. Due to the importance and need to reduce environmental impacts, plan the use of water resources and achieve an efficient and sustainable production process, many researchers have focused their studies on effluent treatment techniques designed to remove these nutrients. This article therefore presents an updated review of the main physicochemical and biological techniques used in the removal of nutrients, which can mitigate environmental problems arising from aquaculture activities and contribute to the sustainability of the activity.
\end{abstract}

Keywords: biological removal, nitrogen compounds, sustainable activity.

\section{Remoção de nutrientes da água residual da aquicultura: uma revisão}

\section{RESUMO}

A aquicultura é uma das atividades que desempenha um papel importante no abastecimento de alimentos ricos em proteínas, atendendo à crescente demanda por pescados. No entanto, a aquicultura é considerada uma atividade potencialmente poluidora, principalmente ao que se refere a poluição hídrica, devido ao descarte indevido de efluentes provenientes do processo produtivo. Os efluentes aquícolas são ricos em nutrientes (amônia, nitrato, nitrito e fósforo) e matéria orgânica, e comumente são lançados no meio ambiente sem o devido tratamento, podendo causar uma série de impactos ambientais e agravar a crise hídrica vivenciada na atualidade. Devido à importância e à necessidade de reduzir os impactos ambientais, planejar de forma eficiente a utilização dos recursos hídricos e alcançar um processo produtivo eficiente e sustentável, muitos pesquisadores têm focado seus estudos em técnicas de tratamento de efluentes voltadas para remoção desses nutrientes. Sendo assim, este artigo visa apresentar uma revisão atualizada das principais técnicas físico-químicas e biológicas, utilizadas na remoção de nutrientes, que podem mitigar os problemas ambientais provenientes da atividade aquícola e contribuir para sua sustentabilidade.

Palavras-chave: atividade sustentável, compostos de nitrogênio, remoção biológica.

This is an Open Access article distributed under the terms of the Creative Commons Attribution License, which permits unrestricted use, distribution, and reproduction in any medium, provided the original work is properly cited. 


\section{INTRODUCTION}

Fishing is one of the oldest activities practiced by man to obtain protein-rich foods. Over the years, fishing activity has undergone a series of technological advances, evolving from artisanal activity to industrial activity. As a result of industrial fishing and the need to meet the growing world demand for food, the supply of fish in natural environments has decreased considerably, causing a decline in activity income. Thus, the sufficient supply of proteins to meet the world demand has become one of today's great challenges (Crab et al., 2007; Nie et al., 2020).

The decline in fishing income and population expansion have driven the growth of aquaculture, which in recent years has played an important role in the global supply of proteinrich foods (Hlordzi et al., 2020; Huang et al., 2020; Manju et al., 2009). According to the Food and Agriculture Organization of the United Nations (FAO, 2020), in 2018 the world production of fish was 179 million tons, of which 82 million tons came from aquaculture. That was responsible for $46 \%$ of total fish production and 52\% of fish production for human consumption. Future projections suggest that, in order to keep up with population growth and to meet the growing demand for fish, aquaculture production should increase, on average, between $60 \%$ to $100 \%$ in the next 20-30 years (FAO, 2020; Turcios and Papenbrock, 2014; Webb et al., 2012).

The need to achieve food security and to produce more and more protein foods has driven the intensification and rapid expansion of aquaculture activity (Manju et al., 2009). However, as in all production processes, the expansion of activity has caused a series of environmental impacts, mainly those related to the improper discharge of untreated wastewater, contributing to the pollution of water resources (Chávez-Crooker and Obreque-Contreras, 2010; Hlordzi et al., 2020; Turcios and Papenbrock, 2014). In addition to causing the degradation of water resources and a series of imbalances in aquatic life, aquaculture is an activity that requires large volumes of water. In traditional shrimp farms, for example, with ponds of up to 10 hectares and which have the capacity to produce more than 10 tons of shrimp/ha per year, between 20 and 64 cubic meters of water are needed for each $1 \mathrm{~kg}$ of shrimp produced (de Melo Filho et al., 2020; Krummenauer et al., 2014), because there is a need for frequent water changes in the production tanks ( 5 to $20 \%$ of the total volume/day) for the good development of the animals. Water resources are of paramount importance for the development of any economic activity and, currently, there are serious problems related to water scarcity in the world, and the limitation of this resource is one of the biggest challenges facing aquaculture today (Chen $e t$ al., 2014; de Melo Filho et al., 2020; Krummenauer et al., 2014; Manju et al., 2009).

One of the main problems related to wastewater from aquaculture activity involves the accumulation of nitrogen compounds (ammonia, nitrite and nitrate), phosphorus, solids and organic matter (Crab et al., 2007; Mook et al., 2012; Turcios and Papenbrock, 2014). These nutrients mainly come from animal feed. According to Mangarengi et al. (2020), from the food offered to the animals raised, only $30 \%$ of the feed is absorbed by their organism, while $70 \%$ is not consumed and is excreted, contributing to the accumulation of nutrients in the tanks. The effluents generated in aquaculture activity differ in quality and quantity of their components, according to the cultivated species and the type of cultivation system adopted. The methods of intensive and semi-intensive cultivation require a greater amount of inputs, such as food and chemical additives, which end up favoring the accumulation of nutrients in the production tanks and generating a large amount of solid waste (Chatla et al., 2020; Mangarengi et al., 2020).

In addition to environmental impacts, such as eutrophication of water bodies, reduction of dissolved oxygen, imbalance in ecosystems, death of aquatic species and contamination of groundwater, which are caused by the improper disposal of untreated wastewater, the accumulation of nutrients and residual organic matter in the cultivation tanks can harm 
aquaculture production. The poor quality of the water in the tanks, caused mainly by the accumulation of nutrients, make these environments conducive to the proliferation of pathogens, contributing to weight loss, malformation, intoxication, stress and death of the cultivated animals (Hlordzi et al., 2020; Ni et al., 2020; Song et al., 2011; Zoppas et al., 2016). In addition to environmental and productive problems, wastewater may contain other contaminants, such as heavy metals, hormones or antibiotics, which can also cause problems to human health (Chatla et al., 2020; Turcios and Papenbrock, 2014).

Considering the socio-environmental and economic impacts caused by aquaculture, it is extremely important that wastewater from aquaculture receive adequate treatment before being released into the environment, thus reducing the negative environmental impacts generated and bringing the activity closer to a more sustainable productive process. Thus, the objective of the present article was to conduct a review of the main techniques used in the treatment of wastewater from aquaculture, especially fish and shrimp farming activities.

\section{METHODS, RESULTS AND DISCUSSION}

The most cited words in the analyzed documents are shown in Figure 1. First, it displays the number of occurrences of the words by the size of the circles, in which the larger the circle, the more the word was mentioned, as well as the year of occurrence represented by the color.

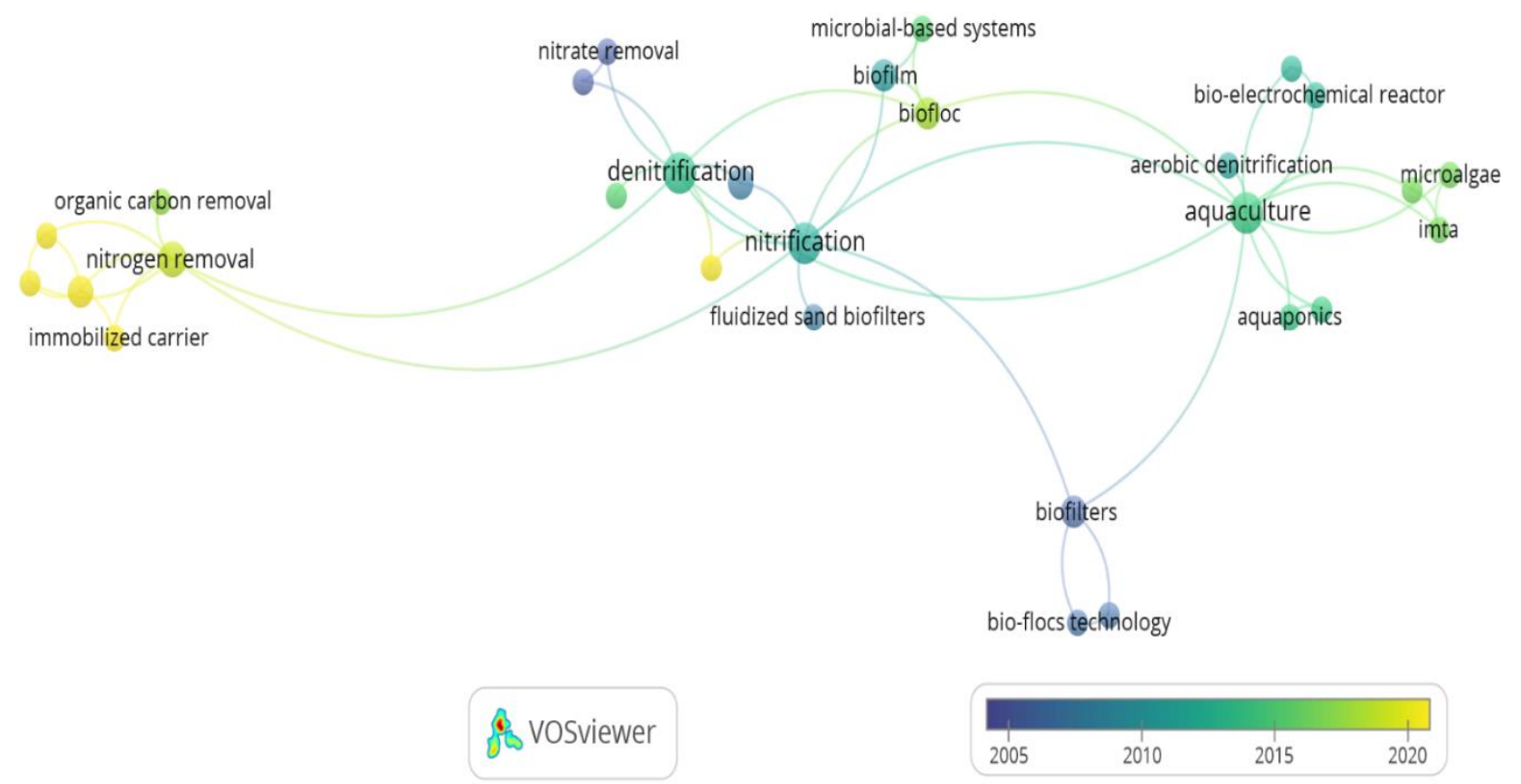

Figure 1. Analysis of the occurrence of words.

Aquaculture is constantly growing and has been causing a series of environmental problems. With worsening availability of drinking water in the world, it is extremely important and urgent that the activity is developed in a sustainable way. For this, it is necessary to constantly search for techniques to remove nutrients and for more efficient cultivation systems that can provide a reduction in environmental impacts, as well as the treatment and reuse of water.

According to Figure 1, it is possible to see that over the last decades the search for wastewater treatment techniques generated in aquaculture has increased. Between 2005 and 2010, interest in nutrient removal techniques such as nitrate, nitrite and ammonia increased, since the most cited words in the literature in this period refer to nitrate removal, biofloc technology and aquaculture, being the physicochemical processes, most reported in the literature. 
After 2010, the number of articles in the literature that showed interest in biological treatment techniques, mainly for the removal of nitrogenous compounds, increased. Most of the studies highlight the most sustainable and economically viable technologies, such as biological denitrification, integrated multi trophic aquaculture (IMTA) systems, as well as the use of microalgae, aquaponics and wetlands to remove nutrients.

Currently, there are several technologies that are used to remove nutrients such as nitrogen compounds, organic matter and phosphorus from wastewater generated in aquaculture. Among these techniques, physicochemical and biological processes continue to stand out.

There are several techniques for removing nutrients from wastewater by means of aquaculture activities, and the physicochemical and biological methods are among them. Biological methods have aroused the interest of researchers from all over the world for presenting satisfactory results in the removal of nutrients, in addition to the low operational cost when compared with physicochemical methods (Mook et al., 2012).

When analyzing the documents selected for the preparation of this review, the huge interest of researchers in developing and optimizing technologies that are efficient in removing contaminants from wastewater generated in aquaculture was evident, mainly in technologies based on biological removal, since most of the studies analyzed focus on biological treatment to remove nutrients that enable their disposal without damaging the environment and/or that allow the reduction of water exchange in the cultivation tanks, thus minimizing the consumption of drinking water in aquaculture activity. Still, it is important to emphasize that aquaculture encompasses a series of production activities, such as shrimp farming, fish farming and frog farming, among others. The wastewaters from these activities have different characteristics and their pollutants differ in quality and quantity. It is necessary that the methods used for the treatment of wastewater are evaluated according to the needs of each activity.

\subsection{Physicochemical treatment techniques used to remove nutrients from aquaculture wastewater}

Before being released into the environment, effluents must undergo a treatment process to remove contaminants that can cause problems to ecosystems. The physicochemical treatments of wastewater require certain steps to promote the removal of contaminants, such as coagulation, flocculation, grating, filtration, $\mathrm{pH}$ correction, ion exchange, disinfection, oxidation, chemical transformation, reverse osmosis, among others (Mook et al., 2012).

Normally, wastewater is subjected to physicochemical treatments to control pollutants that have not been removed by conventional biological processes. Among the physicochemical processes used to remove pollutants, the adsorption method is one of the most used in aquaculture to remove organic contaminants, thus promoting the recovery and purification of the effluent.

Adsorption is the adhesion of one or more substances from a gas, liquid or solid (adsorbate) to an insoluble solid surface (adsorbent). In this process, the contaminant removal mechanism is based on the imbalance of attractive forces present on the surface of the adsorbent solid. Thus, when the adsorbent comes into contact with the adsorbates, there is an interaction between the fields of force of the solid and liquid surfaces, balancing the forces, attracting and retaining the molecules on the surface of the adsorbent (Maroneze et al., 2014).

Factors such as surface area, porosity, chemical surface of the adsorbent compound, molecular weight, molecular size and geometry, solubility, polarity of the adsorbate, interaction between the adsorbent and the adsorbate, contact time, $\mathrm{pH}$ and temperature of the medium can interfere with the adsorption process (Bansal and Goyal, 2005). According to Sauer (2006), the structure of the adsorbent is one of the most important factors to be considered, since compounds with smaller molecular diameters have greater adsorption capacity.

Several materials are used as adsorbents to remove contaminants from wastewater, such as alumina, coal and activated silica, synthetic polymers, and some natural adsorbents. 
However, depending on the adsorbent material used, the process becomes economically unfeasible for the treatment of effluents, as in the case of the use of ion exchange resins due to its limited application and high cost (Scheeren et al., 2011).

One of the most used adsorbent materials is activated carbon, due to its large porous surface area and high adsorption capacity. In addition, it has high thermal stability, low acid/base reactivity and can be recovered after saturation and later reused in the process (Mook et al., 2012; Scheeren et al., 2011).

Another method that can be used for wastewater treatment is membrane filtration treatment. Membranes are barriers that allow separating two phases and restrict the selective passage of materials, according to their size, shape and characteristics. Due to the different dimensions of the pores, membranes are used both to remove solids, viruses and bacteria, and to remove ions of different molecular weights (Freddi, 2019). Membranes are produced using organic polymers and inorganic polymers based on metals, glass or ceramic materials, and can be classified as isotropic and anisotropic, according to their morphology, and dense or porous, according to the characteristics of their surface. In general, despite their higher production cost, membranes made from inorganic materials are more used than membranes based on organic materials, as they have a longer service life and allow for more efficient cleaning (Souza et al., 2021).

The use of separation processes with filtering membranes can be one of the solutions for the treatment of aquaculture wastewater, since filtration systems such as microfiltration (MF), ultrafiltration (UF), nanofiltration (NF) and reverse osmosis (OR) are able to remove organic and inorganic contaminants, as well as bacteria, protozoa and viruses, enabling the reuse of water in the process (Freddi, 2019). Although the OR process is widely used in desalination processes, it can also be applied in wastewater treatment and water reuse to remove phosphates, calcium, heavy metals, color and organic matter. In the filtration process, the medium to be treated passes through the membrane due to the pressure difference between its sides, retaining the desired contaminant (Pires, 2017). The filtration systems differ from each other through the pore sizes of the membranes as follows: for MF, the membranes have pores from 0.1 to 10 microns; for UF, they have pores from 0.1 to 0.01 microns; for NF, pores from 0.01 to 0.035 microns, and for OR they have pores of 0.0001 to 1 micron. The filtration systems also can be classified as a function of the pressure required of the retained material and the retention mechanism, with the pressure used in each of the processes in accordance with the pore size of each membrane (Souza et al., 2021).

Although many types of filters are used as filter media in wastewater treatments, one of the advantages of using membranes is their ability to retain contaminants on a molecular scale, such as salts and ions. In addition, they have other advantages such as energy savings, the technology is clean and easy-to-operate, and they enable the recovery of products that have high added value and can be applied in hybrid treatment processes (Souza et al., 2021).

Regarding the OR process, Mook et al. (2012) highlight as advantages high efficiency in the permeability of selective ions, low production cost, potential to remove ions, proteins and organic compounds and also the fact that normally there is no accumulation of products in the membrane in the process. As a disadvantage, it is a costly process, mainly related to energy and, in some cases, the membrane may become encrusted, impairing its performance and making the process more expensive.

Expandable granular biofilters (EGBs) are another method that can be used to remove contaminants from aquaculture wastewater, especially in partial or total water recirculation (RAS) systems. They are widely used in fish farming, mainly in the removal of solids and nutrients (Kubitza, 2006; Turcios and Papenbrock, 2014) and can operate both as physical and biological filters. Expandable granular filters use low-density floating spheres such as plastic or polystyrene spheres with diameters ranging from 1 to 3 millimeters $(\mathrm{mm})$ and are operated 
in downward flows. They are sized as a physical filter (clarifier) to remove solids and simultaneously facilitate the growth of nitrifying bacteria, which adhere to the spheres and are capable of removing nutrients dissolved in the medium through the biofiltration process. Usually, this type of filter operates as a physical filter. The removal process of this type of filter is similar to sand filters; however, filters with floating spheres do not have problems with hardening, which affect sand filters when exposed to high organic loads (de Miranda, 2012). The wastewater is included in the filter, with a downward flow, and the solids are retained through the layers of spheres, which, due to their porosity, prevent the passage of contaminants. With a filtration cycle, it is possible to remove about $50 \%$ of fine solids and practically all solid material above $50 \mathrm{~mm}$. When several filtration cycles are carried out, it is possible to obtain the complete removal of solids and the biofiltration processes are activated (Steicke et al., 2007).

In the biofiltration process, each sphere is coated with a thin film of bacteria, heterotrophic and autotrophic nitrifying, which promote the retention of nutrients, such as ammonia, nitrate and nitrite, as the water passes through the filter. Upon reaching the saturation of the spheres, the cleaning of the bed can be carried out by mechanical, hydraulic or pneumatic means, releasing solids and the excess bioflakes, thus restoring the filtration capacity. According to Turcios and Papenbrock (2014), the removed sludge has potential applications for composting, vermiculture and fertilizers in agriculture, due to the high concentration of organic matter and nutrients. The disadvantage of this method is related to its high cost, since it requires a significant capital investment and demands a high consumption of energy and maintenance.

\subsection{Biological treatment techniques used to remove nutrients from aquaculture wastewater}

Biological processes are among the most studied treatment techniques today, due to the low cost of installation and operation, when compared to physicochemical treatments (Mook et al., 2012; Scheeren et al., 2011).

Biological processes are widely used to remove nutrients from effluents from different agro-industrial activities. Normally, the processes of removal of nitrogen compounds by the conventional method occur in two separate units, which are based on the combination of aerobic and anoxic processes, and basically consist of the nitrification and denitrification processes, being among the main natural processes involved in the biogeochemical cycle of nitrogen, which are carried by autotrophic and heterotrophic bacteria, respectively (Alves et al., 2018).

The nitrification process is carried out by means of two groups of aerobic bacteria, characterized by the obtention of their energy through the oxidation of inorganic compounds $\left(\mathrm{NH}_{4}\right.$ and $\left.\mathrm{NO}_{2}\right)$. As a carbon source, they use inorganic carbon $\left(\mathrm{CO}_{2}\right)$ and, as an electron acceptor, they use oxygen $\left(\mathrm{O}_{2}\right)$. These bacteria are responsible for nitritation, in which the oxidation of ammonia to nitrite occurs, generating hydroxylamine $\left(\mathrm{NH}_{2} \mathrm{OH}\right)$ as an intermediate product, and for nitration, in which the oxidation of nitrite to nitrate occurs (Zoppas et al., 2016).

The group formed by bacteria of the genus Nitrosomonas, Nitrosococcus and Nitrospira are responsible for the oxidation of ammonia to nitrite, while the group formed by bacteria of the genus Nitrospira, Nitrobacter, Nitrospina and Nitrococcus promote the oxidation of nitrite to nitrate. The oxidation reactions of ammonia to nitrite and the oxidation of nitrite to nitrate are represented in Equations 1 and 2, respectively (Alves et al., 2018).

$$
\begin{aligned}
& \mathrm{NH}_{4}^{+}+1,5 \mathrm{O}_{2} \rightarrow 2 \mathrm{H}^{+} \mathrm{H}_{2} \mathrm{O}+\mathrm{NO}_{2}^{-}+\text {energy } \\
& \mathrm{NO}_{2}^{-}+0,5 \mathrm{O}_{2} \rightarrow \mathrm{NO}_{3}^{-}+\text {energy }
\end{aligned}
$$

As they are bacteria that need oxygen, dissolved oxygen (DO) in the medium becomes a limiting factor in the nitrification process, as well as the temperature and $\mathrm{pH}$ can inhibit the 
growth of bacteria and interfere in the process of removing contaminants. According to Crab et al. (2007), low dissolved oxygen concentrations $\left(<2 \mathrm{mg} \mathrm{L}^{-1}\right)$ can partially or totally limit the development and activity of nitrifying bacteria.

Regarding temperature, Zoppas et al. (2016) mention that temperatures below $10^{\circ} \mathrm{C}$ and above $35^{\circ} \mathrm{C}$ significantly affect the growth rate of nitrifying bacteria, while temperatures between $25^{\circ} \mathrm{C}$ and $35^{\circ} \mathrm{C}$ are considered optimal temperatures and favor their development.

Freddi (2019) reports that the most favorable $\mathrm{pH}$ ranges for the development of nitrifying bacteria are between 6.5 and 8.0. The $\mathrm{pH}$ is an important factor for determining the balance between ionized and non-ionized substances and favoring or inhibiting the growth of ammonia oxidizing bacteria $(\mathrm{AOB})$ and nitrite oxidizing $(\mathrm{NOB})$, since a $\mathrm{pH}$ greater than 8 favors the formation of ammonia and, consequently, the development of $\mathrm{AOB}$, and at a $\mathrm{pH}$ lower than 6 inhibits the activity of both bacteria.

The denitrification processes, in turn, are anoxic processes; that is, they occur in the absence of oxygen but in the presence of nitrates, in which nitrates replace oxygen and are used as electron acceptors by heterotrophic bacteria. The process promotes the reduction of nitrate to nitrogen gas $\left(\mathrm{N}_{2}\right)$, and is carried out by bacteria of the genera Alcaligenes, Archromobacter, Thiosphaera, Rhodopseudomonas, Methanofollis sp., Bacillus sp., Pseudomonas sp., Paracoccus sp. and Enterococcus, which use nitrate in their respiratory process, removing nitrate from the medium (Deng et al., 2021; John et al., 2020). As in nitrification processes, denitrification processes can also be affected by some operational factors, such as $\mathrm{pH}$, temperature, amount of organic carbon $(\mathrm{C} / \mathrm{N}$ ratio) present in the medium and the concentration of DO, since the denitrification is anoxic and DO concentrations above $2 \mathrm{mg} \mathrm{L}^{-1}$ significantly limit the development and activity of denitrifying bacteria, which can lead to the accumulation of intermediate substances such as nitrite, nitric oxide and nitrous oxide (Zoppas et al., 2016).

In biological treatments, operating costs are essentially related to aeration needs in the nitrification step and the addition of an external source of organic carbon in the heterotrophic denitrification step (Zoppas et al., 2016). Organic carbon concentrations are important for the denitrification process to take place, since bacteria use organic carbon as an energy source. In wastewater with a low carbon/nitrogen ratio (less than 2.5), it is necessary to add an external organic carbon source (Zhao et al., 2018).

Many works have mentioned the Anammox (anaerobic ammonium oxidation) processes as a very promising process for the removal of nutrients from aquaculture wastewater, which can also be used in the treatment of sanitary effluents, industrial effluents, swine effluents, saline water treatment and slurry. In the Anammox process, the oxidation of ammonia and the reduction of nitrite occur simultaneously in an anaerobic medium, obtaining $\mathrm{N}_{2}$ as the final substance (Scheeren et al., 2011; van Rijn et al., 2006). This process is carried out by Anammox bacteria, which belong to the Planctomycetes phylum and has eleven genera: Pirellula, Rhodopirellula, Blastopirellula, Planctomyces, Gemmata, Isosphaera, Brocadia, Kuenenia, Scalindua, Anammoxoglobus and Asian Jettenia. These bacteria have a low growth rate, strong affinity with nitrite and ammonium, are found in wastewater and also in natural systems, such as mangroves, the ocean, estuarine sediments and freshwater lakes. However, due to their low rate of duplication, a large amount of inoculum is needed to carry out aquaculture wastewater treatment (Chávez-Crooker and Obreque-Contreras, 2010; Ni et al., 2020; Scheeren et al., 2011).

Anammox processes are also influenced by factors such as temperature, $\mathrm{pH}, \mathrm{DO}, \mathrm{C} / \mathrm{N}$ ratio and concentration of nitrogen present in the medium. According to Scheeren et al. (2011), the Anammox process is favored at temperatures between $25^{\circ} \mathrm{C}$ and $40^{\circ} \mathrm{C}$, which may vary according to the genus of bacteria used, and at low temperatures the bacterial activity is considerably reduced. The ideal $\mathrm{pH}$ range for the development of bacteria is between 6.5 and 8.5 , while in very acidic or very basic $\mathrm{pH}$ ranges, they can favor the increase in the concentration 
of ammonia and nitrous acid, which inhibits the development of Anammox bacteria.

Ni et al. (2020) report that the anammox process is favored in wastewater that has a low carbon/nitrogen $(\mathrm{C} / \mathrm{N})$ ratio; that is, with a high concentration of ammonium and a low concentration of organic matter, thus reducing operating costs with the addition of an external carbon source, used for the growth of heterotrophic bacteria in the conventional biological denitrification method.

For Alves et al. (2018), the main advantages of using the Anammox process to remove nitrogenous compounds are related to robustness, lower oxygen consumption, which is consumed when there is no source of nitrite, as well as the fact that it does not need external sources of carbon and its versatility. The Anammox process is capable of removing 10 times greater loads of contaminants and consumes about 60\% less energy when compared to conventional biological removal processes (Scheeren et al., 2011).

Another process of nitrification and biological denitrification that has attracted the attention of researchers is the simultaneous nitrification-denitrification (SND) process, an alternative for optimizing the process for removing nitrogenous compounds. Unlike conventional denitrification and Anammox processes, in this process, nitrification and denitrification occur simultaneously, in the same reactor and under the same operating conditions. SND removal is performed by heterotrophic aerobic nitrification and denitrification (HNDA) bacteria (Deng et al., 2021), and the removal process occurs within the biofilm due to the biomass oxygen gradient, which favors the simultaneous propagation of the bacteria nitrifying and denitrifying due to uneven oxygen distribution. Thus, nitrifying bacteria are found in areas of the biofilm that have the highest concentration of DO, while denitrifying bacteria are found in areas where OD is limited (Zoppas et al., 2016).

HNAD bacteria have a higher growth rate and higher nitrogen removal capacity when compared to autotrophic bacteria and are more tolerant to different conditions and environments, favoring a more efficient removal of contaminants. Some strains of HNAD bacteria have been extensively studied and have been found and isolated from different environments, such as Acinetobacter, Bacillus, Cupriavidus, Halomonas, Klebsiella, Marinobacter, Pseudomonas and Photobacterium (Huang et al., 2020). According to Deng et al. (2021), HNAD bacteria are not limited to the presence of dissolved oxygen in aquaculture systems, presenting high denitrification efficiency. However, despite being able to reach the stationary phase in 24 hours with an average efficiency of $90 \%$ of removal of nitrogen, for the complete process of nitrification to occur, the HNAD bacteria require a longer period, which can reach weeks.

To obtain a complete simultaneous removal process, it is necessary that the nitrification rate and the denitrification rate are similar. For this, it is necessary that the organic substrate is a substance with low degradability so that the process is not compromised, since nitrification is generally slower compared to denitrification. In addition, factors such as temperature, $\mathrm{pH}, \mathrm{DO}$, $\mathrm{C} / \mathrm{N}$ ratio, form of aeration and age of the sludge can also interfere with the efficiency of removal of contaminants (Zoppas et al., 2016).

As an advantage, the use of simultaneous nitrification and denitrification processes promotes a reduction in the surface used, which translates into savings in space and infrastructure. In addition, COD and nitrogen removal are one of the advantages of these systems, providing a 30-40\% reduction in electrical energy consumption in aeration when compared to conventional nitrification and denitrification processes (Deng et al., 2021).

As a way to optimize the process of nitrification and biological denitrification, many researchers have turned their studies to the application of bacterial consortia to remove nutrients from aquaculture wastewater. Bacterial consortia consist of the use of two or more populations of bacteria of different species that act together, in a combination in which all are benefited due to the activities practiced by each species. However, the efficiency of the process depends a lot 
on finding the right bacteria that have the capacity to remove contaminants, so that the degradation process takes place (John et al., 2020).

Studies by Huang et al. (2020), in which 25 strains of bacteria were tested, showed that most of the tested bacterial consortium presented removal between $45-55 \%$ of $\mathrm{NH}_{4}{ }^{+}-\mathrm{N}$, while the single strains showed removal between $35-45 \%$ of ammonia after 12 hours of cultivation, which makes it evident that bacterial consortium are more efficient at removing ammonia from wastewater. Effective results regarding the use of a bacterial consortium have also been described by John et al. (2020), who confirmed the efficiency of the bacterial consortium in converting ammonia into nitrite and less toxic nitrate, reaching a fish survival rate in the tanks of $97.2 \pm 0.58 \%$, while in the control tanks, without addition of bacteria, fish died from ammonia toxicity.

For aquaculture to be a sustainable activity, the treatment of wastewater from the production process is a mandatory requirement. Over the years, a researcher has focused on several ways to optimize biological processes, in order to achieve higher percentages of removal of pollutants from aquaculture wastewater (Mook et al., 2012). Some studies are shown in Table 1.

\section{CONCLUSION}

Aquaculture contributes to the world's food security, meeting the growing demand for protein-rich foods. However, the activity is considered one of the main causes of water pollution, because aquaculture generates wastewater rich in nutrients such as nitrogen compounds and organic material, which lead to a series of environmental impacts when released without prior treatment into the receiving water bodies.

Over the years, in order to reduce the environmental impacts of aquaculture activity, research has focused on the development of technologies capable of efficiently removing pollutants present in wastewater. Among the many technologies studied, present in the analyzed literature, it was evident that there was a growing interest in biological technologies and in ways to optimize these processes, in order to increase biological efficiency in the removal of contaminants for aquaculture wastewater treatments. The preference for technologies occurs mainly because they are lower in cost when compared to the physical chemical processes. 
Table 1. Techniques for removing nitrogenous compounds from aquaculture wastewater.

\begin{tabular}{|c|c|c|c|}
\hline $\begin{array}{l}\text { Document } \\
\text { Type }\end{array}$ & Techniques covered & Main results & Reference \\
\hline Review & $\begin{array}{l}\text { Integrated Multi Trophic } \\
\text { Aquaculture (IMTA); } \\
\text { Nitrification and } \\
\text { denitrification; Anammox } \\
\text { (Anaerobic Oxidation of } \\
\text { Ammonia); Wetlands }\end{array}$ & $\begin{array}{l}\text { This review addresses methods such as IMTA, biological } \\
\text { nitrogen removal through nitrification and denitrification, } \\
\text { anammox and wetlands, techniques that are being studied to } \\
\text { increase the efficiency in removing nitrogen and other } \\
\text { nutrients in situ from cultivation sites. }\end{array}$ & $\begin{array}{l}\text { Chávez-Crooker and Obreque-Contreras } \\
\text { (2010) }\end{array}$ \\
\hline Research & $\begin{array}{l}\text { Biological nitrification } \\
\text { and denitrification using a } \\
\text { reactor in a biofloc } \\
\text { system }\end{array}$ & $\begin{array}{l}\text { The nitrogen removal process took place over the } \\
\text { experimental period. On the } 4 \text { th day, nitrogen removal became } \\
\text { stable with an average efficiency of } 71.28 \pm 5.28 \% \text {. } \\
\text { Operational variables were controlled throughout the system, } \\
\text { such as pH at } 8.26 \pm 0.1 \text {, temperature at } 28.7 \pm 1.1^{\circ} \mathrm{C} \text { and } \\
\text { dissolved oxygen at } 0.51 \pm 0.41 \mathrm{mg} \mathrm{L}^{-1} \text {. }\end{array}$ & de Melo Filho et al. (2020) \\
\hline Review & $\begin{array}{l}\text { Simultaneous biological } \\
\text { nitrification and } \\
\text { denitrification }\end{array}$ & $\begin{array}{l}\text { Review on the process of biological nitrogen removal from } \\
\text { wastewater, addressing the main parameters that influence the } \\
\text { removal of the contaminant, emphasizing the simultaneous } \\
\text { process of nitrification and denitrification. }\end{array}$ & Zoppas et al. (2016) \\
\hline Review & $\begin{array}{l}\text { Sequencing batch reactor } \\
\text { for biological treatments }\end{array}$ & $\begin{array}{l}\text { This review paper discusses the technical description and } \\
\text { operational flexibility of the SBR for the treatment of a wide } \\
\text { range of effluents under different operating conditions, } \\
\text { together with its modifications that can increase the } \\
\text { effectiveness of the SBR systems in the removal of nitrogen } \\
\text { and phosphorus. }\end{array}$ & Shing and Srivastava (2011) \\
\hline Review & $\begin{array}{l}\text { Aquaculture } \\
\text { Recirculation System } \\
\text { (RAS); Integrated Multi } \\
\text { Trophic Aquaculture } \\
\text { (IMTA); Biofloc } \\
\text { Technology (BFT) }\end{array}$ & $\begin{array}{l}\text { In this review, some aquaculture wastewater treatment } \\
\text { techniques were addressed, such as RAS, IMTA and BFT to } \\
\text { reduce pollution and reuse water. }\end{array}$ & Chatla et al. (2020) \\
\hline
\end{tabular}

Continue...

Rev. Ambient. Água vol. 16 n. 6, e2747 - Taubaté 2021 


\section{Continued...}

\begin{tabular}{|c|c|c|c|}
\hline Research & $\begin{array}{l}\text { Nitrification and } \\
\text { denitrification through a } \\
\text { bacterial consortium }\end{array}$ & $\begin{array}{l}\text { The results showed that the majority of microbial consortia } \\
\text { showed higher efficiency of } \mathrm{NH}_{4}^{+}-\mathrm{N} \text { removal }(45-55 \%) \text { than } \\
\text { single strains }(35-45 \%) \text { after } 12 \mathrm{~h} \text {. In nitrite removal, bacterial } \\
\text { consortia showed a higher removal rate }(58 \%) \text { after } 16 \text { hours, } \\
\text { while single strains showed less efficiency }(30-35 \%) \text {, } \\
\text { suggesting that the removal of ammonia and nitrite by } \\
\text { bacterial consortium is more effective. }\end{array}$ & Huang et al. (2020) \\
\hline Research & $\begin{array}{l}\text { Immobilization of } \\
\text { nitrifying bacteria pools } \\
\text { in wood particles }\end{array}$ & $\begin{array}{l}\text { The nitrifying bacterial consortium was immobilized on the } \\
300-1500 \mu \mathrm{m} \text { particle substrate. The mean removal of TAN } \\
\text { during immobilization was } 3.5 \pm 1.52 \mathrm{mg} \mathrm{L}^{-1} \text { day }^{-1} \text {, while } \\
\mathrm{NO}_{2}-\mathrm{N} \text { and } \mathrm{NO}_{3}-\mathrm{N} \text { were below the detectable limits. The } \\
\text { wood dust sampled on days } 4 \text { and } 5 \text {, showed a potential for } \\
\text { removal of TAN of } 5.67 \pm 1.6 \mathrm{mg} \mathrm{L}^{-1} \text { day }^{-1} \text { and } 5.23 \pm 1.91 \\
\mathrm{mg} \mathrm{L}^{-1} \text { day }^{-1} \text { respectively. There was no significant increase in } \\
\text { the rate of removal of TAN by NBC after } 4 \text { days of } \\
\text { immobilization. }\end{array}$ & Manju et al. (2009) \\
\hline Review & $\begin{array}{l}\text { Immobilization of } \\
\text { anaerobic ammonium } \\
\text { oxidation bacteria; } \\
\text { Anammox (anaerobic } \\
\text { ammonium oxidation) }\end{array}$ & $\begin{array}{l}\text { This review presents the opportunities and challenges found in } \\
\text { the use of cellular immobilization to increase the efficiency in } \\
\text { the removal of nitrogen from wastewater by anammox } \\
\text { bacteria, as well as the existing technologies for anammox } \\
\text { immobilization. Evaluates the sustainability of different gel } \\
\text { carriers and the application of immobilized anammox. }\end{array}$ & Ni et al. (2020) \\
\hline Research & $\begin{array}{l}\text { Isolation and } \\
\text { characterization of } \\
\text { Bacillus sp. Aerobic } \\
\text { denitrifying (strain YX-6) }\end{array}$ & $\begin{array}{l}\text { The results indicated that the YX-6 strain could degrade } \\
\text { nitrogen nitrite from } 10 \mathrm{mg} \mathrm{L}^{-1} \text { to zero in } 14 \text { hours. The rate of } \\
\text { nitrite-N degradation was approximately } 100 \% \text { at the } \\
\text { concentration of dissolved oxygen (DO) of } 5.2-5.8 \mathrm{mg} \mathrm{L}^{-1} \text {. } \\
\text { The aerobic denitrification of the YX-6 strain was greater than } \\
\text { the positive controls under different reaction conditions. }\end{array}$ & Song et al. (2011) \\
\hline
\end{tabular}

\section{Continue...}




\begin{tabular}{|c|c|c|c|}
\hline \multicolumn{4}{|c|}{ Continued... } \\
\hline Review & $\begin{array}{l}\text { Anammox (Anaerobic } \\
\text { ammonium oxidation) }\end{array}$ & $\begin{array}{l}\text { Bibliographic review that presents works published in the last } \\
15 \text { years on studies of the Anammox process, addressing its } \\
\text { metabolic route, the microorganisms involved and the process } \\
\text { control parameters, in addition to studies developed in Brazil } \\
\text { and possible applications. }\end{array}$ & Scheeren et al. (2011) \\
\hline Review & Biological filters & $\begin{array}{l}\text { This paper discusses the implications of the change in the use } \\
\text { of water recirculation systems in freshwater and marine } \\
\text { aquaculture and suggests that for freshwater aquaculture the } \\
\text { emphasis should be placed on cost competitiveness and } \\
\text { intensification of lagoons with RAS biofiltration. In marine } \\
\text { systems, the authors suggest the increase in demand for } \\
\text { oligotrophic and ultra-oligotrophic systems, mainly in nursery } \\
\text { systems. }\end{array}$ & Gutierrez-Wing and Malone (2006) \\
\hline Research & Polymer hydrogels & $\begin{array}{l}\text { The experiments carried out with polymer hydrogels showed } \\
\text { efficient removal of nutrients from aquaculture wastewater. } \\
\text { The removal of } \mathrm{PO}_{4}-\mathrm{P} \text { was } 98 \%, \mathrm{NO}_{3}-\mathrm{N} \text { was } 50 \% \text { and } \mathrm{NO}_{2}-\mathrm{N} \\
\text { was } 85 \% \text {, in a period of } 3 \text { hours of reaction. The results } \\
\text { demonstrate that hydrogels are suitable materials for } \\
\text { aquaculture wastewater treatment. }\end{array}$ & Kioussis et al. (2000) \\
\hline Research & $\begin{array}{l}\text { Ammonia removal with } \\
\text { nitrifying bacteria } \\
\text { immobilized on clay } \\
\text { pallets }\end{array}$ & $\begin{array}{l}\text { The results showed that enriched cultures immobilized on clay } \\
\text { pallets for } 6 \text { hours achieved a removal rate of } 3 \text { mg of TAN L- } \\
1 \text { day }^{-1} \text { during the log removal phase. The immobilized pallets } \\
\text { of } 30 \text { and } 72 \text { hours removed TAN from the culture medium } \\
\text { immediately, showing a removal rate of } 4 \mathrm{mg} \mathrm{L}^{-1} \text { day }^{-1} \text {. } \\
\text { Cultures immobilized for } 30 \text { hours were used to remove TAN } \\
\text { in situ with a density of } 1 \text { pallet/ } 100 \mathrm{~mL} \text {, obtaining removal } \\
\text { rates of } 4.2-6.7 \mathrm{mg}^{-} \text {TAN L } \mathrm{L}^{-1} \text { day }^{-1} \text {. }\end{array}$ & Shan and Obbard (2001) \\
\hline Review & $\begin{array}{l}\text { Electrochemical } \\
\text { technology; Reverse } \\
\text { osmosis; Adsorption; } \\
\text { Wetlands }\end{array}$ & $\begin{array}{l}\text { This article presents a detailed review of physicochemical and } \\
\text { biological techniques used to remove TAN, nitrate and } \\
\text { organic matter. Compares the electrochemical and } \\
\text { bioelectrochemical methods used to remove TAN, nitrate and } \\
\text { organic matter. }\end{array}$ & Mook et al. (2012) \\
\hline
\end{tabular}

Continue... 


\section{Continued...}

Sequencing batch reacto

Research for biological treatments

for low salinity effluents

Internal fibrous biofilter

for intermittent

Research nitrification and

denitrification treatments

Use of Bacillus to

Review maintain water quality in aquaculture

Systems combining aquaculture and plants

Granular expandable biofilters (EGBs);

Wetlands

Biological denitrification using Alcaligenesfaecalis strain in a continuous bioreactor
The results obtained showed that after the aerobic operation of

the reactors, the ammonia concentration dropped from $101 \mathrm{mg}$

$\mathrm{L}^{-1}$ to 0 on day 3 . Nitrate levels increased in the reactor from

33 to $88 \mathrm{mg} \mathrm{L}^{-1}$ on day 3 , reaching 0 on the day 8 when being operated under anoxic conditions. In aerobic activity, the nitrite concentration increased from 260 to $371 \mathrm{mg} \mathrm{L}^{-1}$ and during the anoxic phase, and there was a reduction of nitrite to

$3 \mathrm{mg} \mathrm{L}^{-1}$ on day 8 . With respect to carbon, there was a reduction from 1201 to $32 \mathrm{mg} \mathrm{L}^{-1}$.

Pre-acclimated biofilter, with an initial nitrification rate of

$17.1 \pm 12.4 \mathrm{mg}$ of TAN m $\mathrm{m}^{-2} \mathrm{~d}^{-1}$, was applied in a shrimp tank.

The biofilter's aerobic nitrification activity was sufficient to control ammonia and nitrite levels below $0.2 \mathrm{mg}-\mathrm{N} \mathrm{L}^{-1}$ with nitrate accumulation of up to $50 \mathrm{mg}-\mathrm{N} \mathrm{L}^{-1}$. The nitrate was removed after harvesting with the same biofilter with anoxic denitrification and addition of methanol with a ratio of $5: 1$.

This review highlights the aquaculture activities that lead to pollution and the possible mechanisms used by Bacillus to improve water quality. They recommend that a series of optimal conditions is established to increase the efficiency of Bacillus in modulating water quality.

This review provides an overview of aquaculture systems developed in historical times that may still be valuable for the future, bringing current problems and innovative ideas, especially with regard to the integration of halophytic plants as a biofilter in saline aquaculture systems.

In this work, the viability of a continuous bioreactor was analyzed using the NR strain for simultaneous removal of nitrogen and organic matter (TOC) in a single aerated reactor, instead of batch culture. The results showed removal of 66.7-

Satanwat et al. (2020) $78.3 \% \mathrm{NH}_{4}{ }^{+}-\mathrm{N}$ and $85.8-92.2 \%$ TOC.

\section{Continue...}


Continued...

\begin{tabular}{|c|c|c|c|}
\hline Review & Microbial based systems & $\begin{array}{l}\text { This article presents a review of successful results in the use } \\
\text { of microbial-based systems that have been documented } \\
\text { around the world, as well as some aspects to be considered in } \\
\text { the process and which will still be experienced before a } \\
\text { system is implemented. New advances in the use of } \\
\text { microbial-based systems and recommendations are also } \\
\text { presented. }\end{array}$ & Martínez-Córdova et al. (2015) \\
\hline Research & $\begin{array}{l}\text { Biological nitrification } \\
\text { and denitrification by the } \\
\text { strain Pseudomonas sp. }\end{array}$ & $\begin{array}{l}\text { The results showed that the Pseudomonas strain showed an } \\
\text { efficient capacity for heterotrophic nitrification-aerobic } \\
\text { denitrification. The TAN ( } 10 \mathrm{mg} \mathrm{L}^{-1} \text { ) was completely } \\
\text { removed in } 12 \text { hours. The nitrogen mass balance indicated } \\
\text { that } 70.8 \% \text { of the initial TAN was converted to gaseous } \\
\text { nitrogen and } 28.1 \% \text { to intracellular nitrogen. The optimal } \\
\text { conditions for removal of TAN, nitrate and nitrite were } \mathrm{pH} 7 \\
\text { with } \mathrm{C} / \mathrm{N} \text { ratios of } 8,12 \text { and } 12 \text {, respectively. }\end{array}$ & Deng et al. (2021) \\
\hline Review & $\begin{array}{l}\text { Biological nitrification; } \\
\text { Treatment ponds; } \\
\text { Biological filters; Biofloc } \\
\text { technology; Periphyton } \\
\text { treatment }\end{array}$ & $\begin{array}{l}\text { This review covers techniques for nitrogen removal from } \\
\text { aquaculture wastewater such as rotating biological counters, } \\
\text { drip filters, fluidized sand biofilters and granule filters, as } \\
\text { well as biofloc technology and periphyton treatment, known } \\
\text { as a dual-purpose technique, since it allows to treat } \\
\text { aquaculture water and simultaneously produce fish feed. }\end{array}$ & Crab et al. (2007) \\
\hline Review & Drip filters & $\begin{array}{l}\text { This review addresses the main mechanisms and parameters } \\
\text { that affect the design and performance of drip filters in } \\
\text { aquaculture, relationships between nitrification rates and } \\
\text { parameters that can affect the process kinetics. The filter } \\
\text { design procedures are presented and one of them, a model that } \\
\text { describes the nitrification performance of piston flow drip } \\
\text { filters, is covered in more detail. }\end{array}$ & Eding et al. (2006) \\
\hline
\end{tabular}

Continue...

Rev. Ambient. Água vol. 16 n. 6, e2747 - Taubaté 2021 
Continued...

This study evaluated fluidized sand biofilters as a treatment option to remove $\mathrm{BOD}_{5}$, TAN, total phosphorus, suspended

Research Fluidized sand biofilters solids and total coliforms from aquaculture effluents. Two sand sizes $0.11 \mathrm{~mm}$ and $0.19 \mathrm{~mm}$ were used and two

Davidson et al. (2008) operating techniques were evaluated. Biofilters removed 66$82 \% \mathrm{BOD}_{5}, 86-88 \%$ TAN and $15-41 \%$ phosphorus.

This study presents a catalytic ozonation membrane system

for the treatment of aquaculture wastewater, using Ti-

Research Catalytic ozonation membrane filter $\mathrm{Mn} / \mathrm{TiO}_{2} / \mathrm{Al}_{2} \mathrm{O}_{3}$ and $\mathrm{TiO}^{2} / \mathrm{Al}_{2} \mathrm{O}_{3}$ membranes, with Ti$\mathrm{Mn} / \mathrm{TiO}_{2} / \mathrm{Al}_{2} \mathrm{O}_{3}$ obtaining better catalytic capacity. The results showed that the suspended solids, TAN, $\mathrm{NO}_{2}$ and COD were efficiently removed, obtaining a wastewater recovery rate of $95.8 \%$

The bacterial consortium was tested for 15 days in a tank with controlled conditions. The ammonia concentration in the tanks with the pool was $4.8 \pm 0.068 \mu \mathrm{mL}^{-1}$, while in the

Research Consortium of bacteria control tank (without bacteria) it was $7.29 \pm 0.292 \mu \mathrm{mL}^{-1}$. The nitrite increase $\left(6.9 \pm 0.59 \mu \mathrm{mL}^{-1}\right)$ and nitrate $(4.16 \pm 0.58$

$\left.\mu \mathrm{mL}^{-1}\right)$. The survival rate in the tanks was $97.2 \pm 0.58 \%$, while in the control tanks it was $55 \pm 0.25 \%$.

This article presents a review of the microalgae-based IMTA systems described so far in the literature and evaluates

Integrated Multi Trophic

Review Aquaculture based on microalgae microalgae culture methods that are applied in the treatment of aquaculture wastewater such as periphyton, cell immobilization and pools of microalgae-bacteria.

This review presents an overview of the removal of nutrients based on microalgae from aquaculture residues, challenges

Review Removal of nutrients using microalgae encountered in the development of an efficient treatment system, as well as factors that affect the growth of microalgae and the removal of nutrients. New cultivation strategies are presented to increase biomass production and nutrient removal.

Milhazes-Cunha and Otero (2016)

and the removal of nutrients. New cultivation strategies are
presented to increase biomass production and nutrient
removal.

\section{Continue...}




\begin{tabular}{|c|c|c|c|}
\hline \multicolumn{4}{|c|}{ Continued... } \\
\hline Review & Built wetlands & $\begin{array}{l}\text { The review presents the most recent studies on the use of } \\
\text { wetlands for the treatment of saline wastewater, as well as the } \\
\text { factors that influence the efficiency of wetlands in the } \\
\text { treatment process and how greater efficiency can be achieved } \\
\text { by screening for halophytes, application of halophilic } \\
\text { microorganisms and optimization of operating parameters. }\end{array}$ & Liang et al. (2017) \\
\hline Research & Halophyte filter beds & $\begin{array}{l}\text { In } 88 \text { days of commercial operation on a fish and shrimp } \\
\text { farm, Salicornia europaea plant biofilters removed } 98.2 \pm \\
2.2 \% \text { dissolved inorganic nitrogen, } 23-69 \% \text { dissolved organic } \\
\text { nitrogen and } 36-89 \% \text { inorganic phosphorus dissolved in } \\
\text { routine operations. }\end{array}$ & Webb et al. (2012) \\
\hline Review & $\begin{array}{l}\text { Biological removal of } \\
\text { nitrate by assimilation or } \\
\text { dissimilation; Autotrophic } \\
\text { and heterotrophic } \\
\text { denitrification; Anammox }\end{array}$ & $\begin{array}{l}\text { Biological nitrate removal pathways are presented, as well as } \\
\text { links between denitrifying organisms and carbon in } \\
\text { recirculation systems, applications of biological nitrate } \\
\text { removal in recirculation systems and, finally, the anammox } \\
\text { process is discussed as an alternative for removing ammonia } \\
\text { and nitrate. }\end{array}$ & van Rijn et al. (2006) \\
\hline Research & $\begin{array}{l}\text { Sequencing batch reactor } \\
\text { for biological treatments } \\
\text { of shrimp effluents }\end{array}$ & $\begin{array}{l}\text { The results showed that the initial TAN concentration } \\
\text { dropped from } 72 \text { to } 0 \mathrm{mg} \mathrm{L}^{-1} \text { on day } 4 \text { during the aerobic } \\
\text { mode of operation. The nitrite level increased from } 46 \mathrm{mg} \mathrm{L}^{-1} \\
\text { at the beginning of the experiment to } 198 \mathrm{mg} \mathrm{L}^{-1} \text { on day } 7 \text {, } \\
\text { decreasing to } 0 \text { on day } 15 \text {, when it was operated anoxic. } \\
\text { Nitrate increased in the aerobic period from } 32 \text { to } 162 \mathrm{mg} \mathrm{L}^{-1} \\
\text { on day } 8 \text { and, during the anoxic process, reached } 0 \mathrm{mg} \mathrm{L}^{-1} \text { on } \\
\text { day } 15 . \mathrm{SBR} \text { also removed } 82 \% \text { of organic carbon from the } \\
\text { system. }\end{array}$ & Boopathy (2009) \\
\hline
\end{tabular}




\section{REFERENCES}

ALVES, C. F.; BORTOLUCI, C. B. C.; OLIVEIRA, E. P.; PIZZO, M. M.; RODRIGUEZ, R. P. Remoção biológica de nitrogênio em águas residuárias: uma revisão dos processos convencionais aos processos modernos. Revista Ibero-Americana de Ciências Ambientais, v. 9, n. 3, p. 174-187, 2018. https://doi.org/10.6008/cbpc21796858.2018.003.0015

BANSAL, R. C.; GOYAL, M. Activated carbon adsorption. Boca Raton: CRC Press, 2005. https://doi.org/10.1201/9781420028812

BOOPATHY, R.; BONVILLAIN, C.; FONTENOT, Q.; KILGEN, M. Biological treatment of low-salinity shrimp aquaculture wastewater using sequencing batch reactor. International Biodeterioration and Biodegradation, v. 59, n. 1, p. 16-19, 2007. https://doi.org/10.1016/j.ibiod.2006.05.003

BOOPATHY, R. Biological treatment of shrimp production wastewater. Journal of Industrial

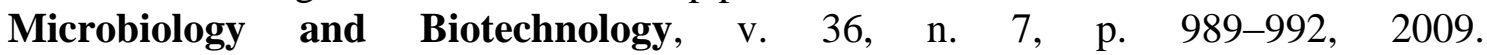
https://doi.org/10.1007/s10295-009-0577-0

CHATLA, D.; PADMAVATHI, P.; SRINU, G. Wastewater treatment techniques for sustainable aquaculture. In: GHOSH, S. K. (ed.). Waste Management as Economic Industry Towards Circular Economy. Singapore: Springer, 2020. p. 159-166.

CHÁVEZ-CROOKER, P.; OBREQUE-CONTRERAS, J. Bioremediation of aquaculture wastes. Current Opinion in Biotechnology, v. 21, n. 3, p. 313-317, 2010. https://doi.org/10.1016/j.copbio.2010.04.001

CHEN, S.; YU, J.; WANG, H.; YU, H.; QUAN, X. A pilot-scale coupling catalytic ozonation - membrane filtration system for recirculating aquaculture wastewater treatment. Desalination, v. 363, p. 37-43, 2014. https://doi.org/10.1016/j.desal.2014.09.006

CRAB, R.; AVNIMELECH, Y.; DEFOIRDT, T.; BOSSIER, P.; VERSTRAETE, W. Nitrogen removal techniques in aquaculture for a sustainable production. Aquaculture, v. 270, n. 1-4, p. 1-14, 2007. https://doi.org/10.1016/j.aquaculture.2007.05.006

DAVIDSON, J.; HELWIG, N.; SUMMERFELT, S. T. Fluidized sand biofilters used to remove ammonia, biochemical oxygen demand, total coliform bacteria, and suspended solids from an intensive aquaculture effluent. Aquacultural Engineering, v. 39, n. 1, p. 6-15, 2008. https://doi.org/10.1016/j.aquaeng.2008.04.002

DE MELO FILHO, M. E. S.; OWATARI, M. S.; MOURIÑO, J. L. P.; LAPA, K. R.; SOARES, H. M. Application of nitrification and denitrification processes in a direct water reuse system for pacific white shrimp farmed in biofloc system. Aquacultural Engineering, v. 88, 2020. https://doi.org/10.1016/j.aquaeng.2020.102043

DE MIRANDA, M. O. T. Cultivo de surubim pintado (Pseudoplatystoma corruscans) e híbrido ( $\boldsymbol{P}$. reticulatum $\boldsymbol{X} \boldsymbol{P}$. corruscans) em sistema de recirculação de água. 2012. 91 f. Tese (Doutorado em Ciências Biológicas) - Universidade Federal de São Carlos, São Carlos, 2012. 
DENG, M.; ZHAO, X.; SENBATI, Y.; SONG, K.; HE, X. Nitrogen removal by heterotrophic nitrifying and aerobic denitrifying bacterium Pseudomonas sp. DM02: Removal performance, mechanism and immobilized application for real aquaculture wastewater $\begin{array}{lllll}\text { treatment. Bioresource } & \text { Technology, } & \text { v. } & 322, & \end{array}$ https://doi.org/10.1016/j.biortech.2020.124555

EDING, E. H.; KAMSTRA, A.; VERRETH, J. A. J.; HUISMAN, E. A.; KLAPWIJK, A. Design and operation of nitrifying trickling filters in recirculating aquaculture: A review. Aquacultural Engineering, v. 34, n. 3, p. 234-260, 2006. https://doi.org/10.1016/j.aquaeng.2005.09.007

FAO. The State of world fisheries and Aquaculture. Rome, 2020.

FREDDI, L. A. Uso de reator de biofilme aerado em membrana no tratamento de efluente de sistema de recirculação aquícola. 2019. Dissertação (Mestrado em Saneamento) Universidade Estadual Paulista, Ilha Solteira, 2019.

GUTIERREZ-WING, M. T.; MALONE, R. F. Biological filters in aquaculture: Trends and research directions for freshwater and marine applications. Aquacultural Engineering, v. 34, n. 3, p. 163-171, 2006. https://doi.org/10.1016/j.aquaeng.2005.08.003

HLORDZI, V.; KUEBUTORNYE, F. K. A.; AFRIYIE, G.; ABARIKE, E. D.; LU, Y.; CHI, S.; ANOKYEWAA, M. A. The use of Bacillus species in maintenance of water quality in aquaculture: A review. Aquaculture Reports, 18, 2020. https://doi.org/10.1016/j.aqrep.2020.100503

HUANG, F.; PAN, L.; HE, Z.; ZHANG, M.; ZHANG, M. Culturable heterotrophic nitrification-aerobic denitrification bacterial consortia with cooperative interactions for removing ammonia and nitrite nitrogen in mariculture effluents. Aquaculture, v. 523, 2020. https://doi.org/10.1016/j.aquaculture.2020.735211

JOHN, E. M.; KRISHNAPRIYA, K.; SANKAR, T. V. Treatment of ammonia and nitrite in aquaculture wastewater by an assembled bacterial consortium. Aquaculture, v. 526, 2020. https://doi.org/10.1016/j.aquaculture.2020.735390

KIOUSSIS, D. R.; WHEATON, F. W.; KOFINAS, P. Reactive nitrogen and phosphorus removal from aquaculture wastewater effluents using polymer hydrogels. Aquacultural Engineering, v. 23, n. 4, p. 315-332, 2000. https://doi.org/10.1016/S01448609(00)00058-3

KRUMMENAUER, D.; SAMOCHA, T.; POERSCH, L.; LARA, G.; WASIELESKY, W. The reuse of water on the culture of pacific white shrimp, Litopenaeus vannamei, in BFT system. Journal of the World Aquaculture Society, v. 45, n. 1, p. 3-14, 2014. https://doi.org/10.1111/jwas.12093

KUBITZA, F. Sistemas de Recirculação: Sistemas fechados com tratamento e reuso da água. Panorama da Aquicultura, v. 16, n. 95, p. 15-22, 2006.

LIANG, Y.; ZHU, H.; BAÑUELOS, G.; YAN, B.; ZHOU, Q.; YU, X. et al. Constructed wetlands for saline wastewater treatment: A review. Ecological Engineering, v. 98, p. 275-285, 2017. https://doi.org/10.1016/j.ecoleng.2016.11.005 
MANGARENGI, N. A. P.; SELINTUNG, M.; ZUBAIR, A.; AHMAD, F. Evaluation of the effectiveness of wastewater treatment plant for super-intensive shrimp farms (A case study on Punaga Village, Takalar). IOP Conference Series: Earth and Environmental Science, v. 419, n. 1, 2020. https://doi.org/10.1088/1755-1315/419/1/012162

MANJU, N. J.; DEEPESH, V.; ACHUTHAN, C.; ROSAMMA, P.; SINGH, I. S. B. Immobilization of nitrifying bacterial consortia on wood particles for bioaugmenting nitrification in shrimp culture systems. Aquaculture, v. 294, n. 1-2, p. 65-75, 2009. https://doi.org/10.1016/j.aquaculture.2009.05.008

MARONEZE, M. M.; ZEPKA, L. Q.; VIEIRA, J. G.; QUEIROZ, M. I.; JACOB-LOPES, E. A tecnologia de remoção de fósforo: Gerenciamento do elemento em resíduos industriais. Revista Ambiente \& Água, v. 9, n. 3, p. 445-458, 2014. https://doi.org/10.4136/ambiagua.1403

MARTÍNEZ-CÓRDOVA， L. R.; EMERENCIANO， M.; MIRANDA-BAEZA， A.; MARTÍNEZ-PORCHAS, M. Microbial-based systems for aquaculture of fish and shrimp: An updated review. Reviews in Aquaculture, v. 7, n. 2, p. 131-148, 2015. https://doi.org/10.1111/raq.12058

MILHAZES-CUNHA, H.; OTERO, A. Valorisation of aquaculture effluents with microalgae: The Integrated Multi-Trophic Aquaculture concept. Algal Research, v. 24, p. 416-424, 2016. https://doi.org/10.1016/j.algal.2016.12.011

MOOK, W. T.; CHAKRABARTI, M. H.; AROUA, M. K.; KHAN, G. M. A.; ALI, B. S.; ISLAM, M. S. et al. Removal of total ammonia nitrogen (TAN), nitrate and total organic carbon (TOC) from aquaculture wastewater using electrochemical technology: A review. Desalination, v. 285, p. 1-13, 2012. https://doi.org/10.1016/j.desal.2011.09.029

NI, S.-Q.; AHMAD, H. A.; AHMAD, S. Immobilization of anaerobic ammonium oxidation bacteria for nitrogen-rich wastewater treatment. In: SHAH, P.; RODRIGUEZ-COUTO, S.; ŞENGÖR, S. S. Emerging Technologies in Environmental Bioremediation. Elsevier, 2020. https://doi.org/10.1016/b978-0-12-819860-5.00001-8

NIE, X.; MUBASHAR, M.; ZHANG, S.; QIN, Y.; ZHANG, X. Current Progress, Challenges and Perspectives in Microalgae-Based Nutrient Removal for Aquaculture Waste: A Comprehensive Review. Journal of Cleaner Production, v. 277, 2020. https://doi.org/10.1016/j.jclepro.2020.124209

PIRES, H. A. Tratamento de efluente da industrialização de pescado com sistema de ultrafiltração. 2017. Dissertação (Mestrado em ciência Animal) - Universidade Estadual Paulista (Unesp), Faculdade de Medicina Veterinária, Araçatuba, 2017.

SATANWAT, P.; TRAN, T. P.; HIRAKATA, Y.; WATARI, T.; HATAMOTO, M.; YAMAGUCHI, T. et al. Use of an internal fibrous biofilter for intermittent nitrification and denitrification treatments in a zero-discharge shrimp culture tank. Aquacultural Engineering, v. 88, 2020. https://doi.org/10.1016/j.aquaeng.2019.102041

SAUER, T. Tratamento de Efluentes de Curtume através do Processo Combinado de Degradação Fotocatalítica Seguida por Adsorção em Carvão Ativado. 2006. 249p. Tese (Doutorado em Engenharia Química) - Universidade Federal de Santa Catarina, Florianópolis, 2006. 
SCHEEREN, M. B.; KUNZ, A.; STEINMETZ, R. L. R.; DRESSLER, V. L. O processo ANAMMOX como alternativa para tratamento de águas residuárias, contendo alta concentração de nitrogênio. Revista Brasileira de Engenharia Agrícola e Ambiental, v. 15, n. 12, p. 1289-1297, 2011. https://doi.org/10.1590/s1415-43662011001200011

SHAN, H.; OBBARD, J. P. Ammonia removal from prawn aquaculture water using immobilized nitrifying bacteria. Applied Microbiology and Biotechnology, v. 57, n. 56, p. 791-798, 2001. https://doi.org/10.1007/s00253-001-0835-1

SINGH, M.; SRIVASTAVA, R. K. Sequencing batch reactor technology for biological wastewater treatment: a review. Asia-pacific journal of chemical engineering, v. 6, n. 1, 2011. https://doi.org/10.1002/apj.490

SONG, Z. F.; AN, J.; FU, G. H.; YANG, X. L. Isolation and characterization of an aerobic denitrifying Bacillus sp. YX-6 from shrimp culture ponds. Aquaculture, v. 319, n. 1-2, p. 188-193, 2011. https://doi.org/10.1016/j.aquaculture.2011.06.018

SOUZA, J. E. S. de; ARAÚJO, B. A.; SARMENTO, K. K. F.; REBOUÇAS, L. D.; MEDEIROS, K. M. de; LIMA, C. A. P. de. Membranas de nanocompósitos poliméricos com óxido de zinco para o tratamento de efluentes: Revisão de literatura. Research, Society and Development, v. 10, n. 8, 2021. https://doi.org/10.33448/rsd-v10i8.17402

STEICKE, C.; JEGATHEESAN, V.; ZENG, C. Mechanical mode floating medium filters for recirculating systems in aquaculture for higher solids retention and lower freshwater usage. Bioresource Technology, v. 98, p. 3375-3383, 2007. https://doi.org/10.1016/j.biortech.2006.10.042

TURCIOS, A. E.; PAPENBROCK, J. Sustainable treatment of aquaculture effluents-What can we learn from the past for the future? Sustainability, v. 6, n. 2, p. 836-856, 2014. https://doi.org/10.3390/su6020836

VAN RIJN, J.; TAL, Y.; SCHREIER, H. J. Denitrification in recirculating systems: Theory and applications. Aquacultural Engineering, v. 34, n. 3, p. 364-376, 2006. https://doi.org/10.1016/j.aquaeng.2005.04.004

WEBB, J. M.; QUINTA, R.; PAPADIMITRIOU, S.; NORMAN, L.; RIGBY, M.; THOMAS, D. N. et al. Halophyte filter beds for treatment of saline wastewater from aquaculture. Water Research, v. 46, n. 16, 2012 https://doi.org/10.1016/j.watres.2012.06.034

ZHAO, B.; TIAN, M.; AN, Q.; YE, J.; GUO, J. S. Characteristics of a heterotrophic nitrogen removal bacterium and its potential application on treatment of ammonium-rich

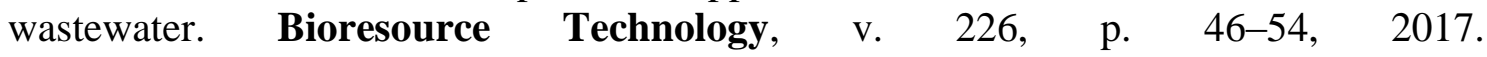
https://doi.org/10.1016/j.biortech.2016.11.120

ZHAO, J.; LI, Y.; CHEN, X.; LI, Y. Effects of carbon sources on sludge performance and microbial community for 4-chlorophenol wastewater treatment in sequencing batch

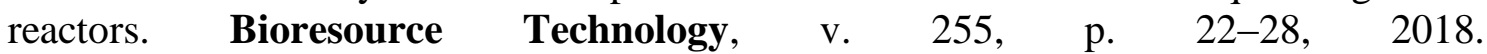
https://doi.org/10.1016/j.biortech.2018.01.106

ZOPPAS, F. M.; BERNARDES, A. M.; MENEGUZZI, Á. Parâmetros operacionais na remoção biológica de nitrogênio de águas por nitrificação e desnitrificação simultânea. Engenharia Sanitaria e Ambiental, v. 21, n. 1, p. 29-42, 2016. https://doi.org/10.1590/S1413-41520201600100134682 